\title{
Mapping the North \\ Ethnicities, Territories and the Networks of Archaeology
}

Carl-Gösta Ojala

\begin{abstract}
The Saami, the indigenous population of northern Fennoscandia, have constantly been conceptualized as the others in relation to the (pre-)history writing of the modern nation-states. Here, the discussion focuses on Saami archaeology and representations of Saami prehistory in Sweden. It is emphasized that all ethnic, national and territorial concepts are embedded in networks of power, and that the connections and separations behind the concepts need to be explored. In this article a relational network approach is suggested as an alternative to dualistic thinking about ethnicities and territories. Ethnicity is here seen as one set of relationships, interwoven into many networks stretching over time and space. The network approach is in part inspired by actor-network theory, which is briefly described together with some possible points of interest for archaeological studies.

Carl-Gösta Ojala, Department of Archaeology and Ancient History, Uppsala University, Box 626, SE-75I 26 Uppsala, Sweden
\end{abstract}

Key words: nationalism, ethnicity, ethnopolitics, actor-network theory, Saami, northern Fennoscandia

One of the most dominant images of northern Sweden is that of the last wilderness and the pristine nature untouched by humans. The North has often been seen as something exotic, as a frontier to be conquered, or as a romanticized, idealized, virgin land - something essentially different from the South. In this context, the Saami - the indigenous population in northern Norway, Sweden, Finland and the Kola Peninsula in the Russian Federation - has often been represented as a homogeneous, traditional and unchanged remnant of the past, especially in many tourist and popular cultural heritage representations (Saarinen 1997; Mulk \& Bayliss-Smith 1999; Olsen K. 2003).

Noel Broadbent discusses what could be called a "longitude 30 degrees latitude 60 degrees syndrome" (see Fig. 1), inherent in archaeological research in Sweden (Broadbent 2001; cf. also Loeffler 2005). Broadbent argues that "Sweden" has constantly been constructed and reconstructed with images and myths taken from the area south of the 60th latitude, thereby denying its northern identity. On the other hand, the 30th longitude has long been a compact barrier to 
the east, cutting Sweden off from its circumpolar context. Broadbent suggests that the greatest potential in archaeological research in Sweden would be to recognize the circumpolar cultural and natural history and to try to understand the meeting and mixture of what he calls the circumpolar and European influences through history in the Nordic area and present-day Sweden. Examples of the divide between what is considered southern Swedish prehistory and northern Swedish prehistory abound in the archaeological literature in Sweden and relate to any prehistoric period. At the same time, archaeological research in the Soviet Union and the Russian Federation remains little known among archaeologists in Sweden 15 years after the breakdown of the iron curtain, even though this research would be very relevant when studying prehistory in northern Sweden. Although the nation-state boundaries in northern Fennoscandia obviously are irrelevant with regard to the prehistoric societies, these boundaries have fundamentally formed and delimited the images of prehistory in the area. Archaeologists have almost exclusively studied only their own national piece of the pie, with the resulting rather odd image of the past as a projection of the political situation of today.

The map (Fig. 1) also shows Sápmi, which is considered today to be the traditional settlement and cultural area of the Saami population. One should, however, be very cautious with well-arranged maps such as this. What do these boundaries really represent? The Saami cultural consciousness is mapped in a two-way process, on the one hand empowering a Saami cultural self-consciousness connected with "the land", but on the other hand presenting "the Saami" as something separate, bounded and limited to a specific territorial area as part of a static, regulated map view, where each people has its place. The notion of Sápmi carries a potential for an alternative geography that stretches across the boundaries of the present-day nation-states, but it comes with a form that fits well into the scheme of nationalist cartography (cf. Conrad 2004).

Archaeologists work across time and space and create images and narratives of the past by linking together a wide variety of materials, places and ideas. Many researchers (e.g., Eriksen 1996) have discussed the importance of a past in creating myths about group identity, and the human need to have the world and one's place in it explained. Archaeology plays an important role as a producer of raw material for myths about group identities that are linked to the past and to the land. In northern Sweden, the archaeological research is a much more controversial activity than in the southern parts of the country, with connections to many sociocultural and political contexts in present-day society, including identity processes and conflicts over places and lands. There is a long history of discrimination and various alternating Swedification and isolation efforts directed by the Swedish state towards the Saami population as well as the Finnish minority population in northern Sweden (see e.g., Lundmark 1998). However, the colonial history and the present "post-colonial" situation in the North are, in my view, not well recognized in Sweden, thus hindering the understanding of many social and cultural processes and the importance of archaeology in these contexts. 


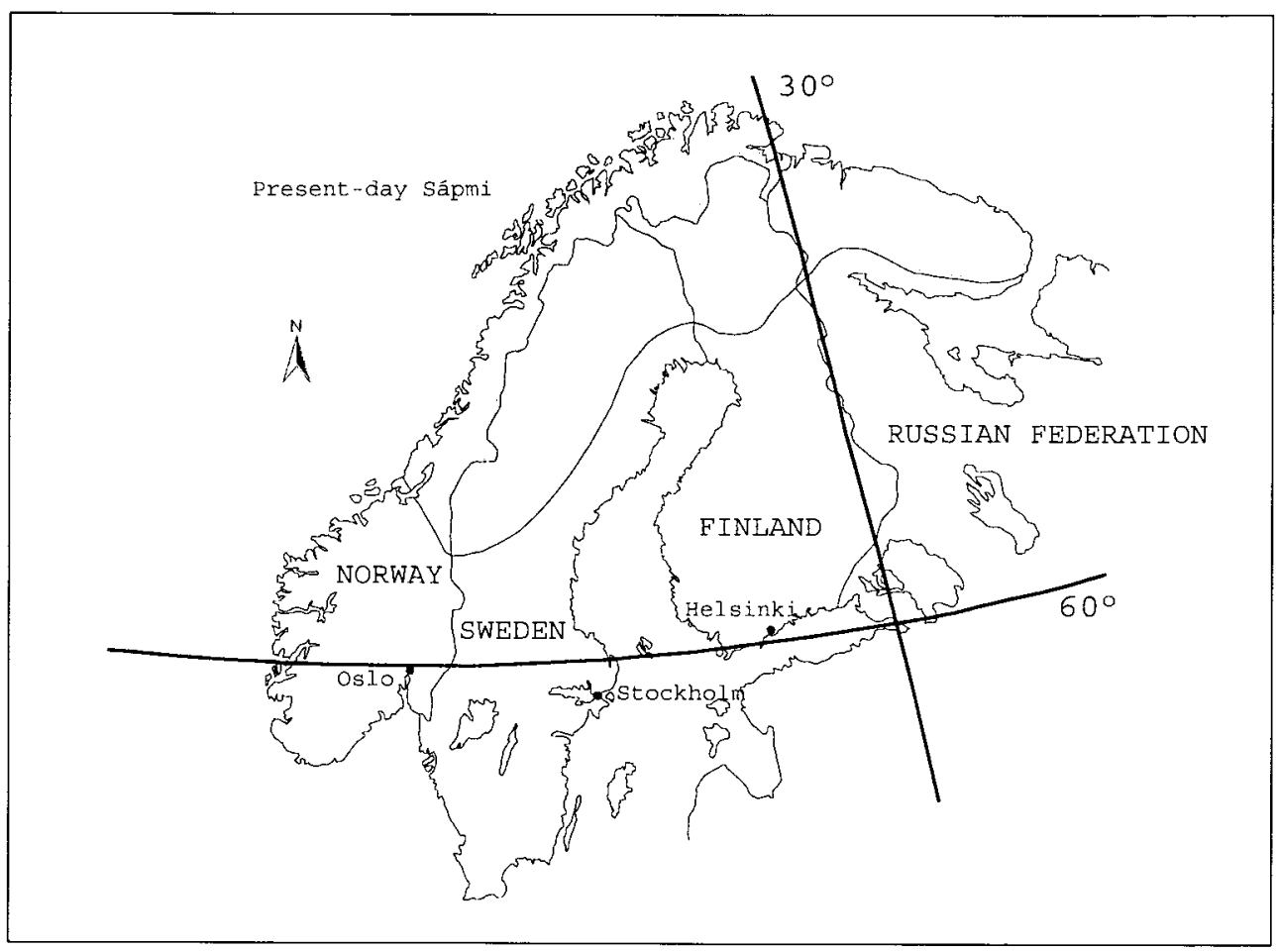

Fig. 1. Sápmi, the present-day traditional cultural area of the Saami population, as it is commonly represented in the literature, and the "longitude 30 degrees - latitude 60 degrees syndrome". Map based on Zachrisson et al. 1997:9 and Broadbent 2001:27.

In this article, I discuss some aspects of the networks of archaeology in the North in relation to the conceptualization of identities. The point of departure is the notion that all ethnic, national and territorial concepts are parts of networks of power, and that archaeologists need to be aware of the power-play involved. In the article, I suggest the use of a relational network approach in order to overcome dualistic thinking and avoid homogeneous "one-entities" and essentialist "blackboxes" when discussing people in prehistory. In doing so, I draw some inspiration from the so-called actor-network theory project, which is described briefly below, and I then explore some ideas of a network approach that might be of interest in archaeological studies.

\section{ONE-ENTITIES AND BLACK-BOXES}

By turning names into things we create false models of reality. By endowing nations, societies or cultures with the qualities of internally homogeneous and externally distinctive and bounded objects, we create a model of the world as a global pool hall in which the entities spin off each other like so many hard and round billiard balls. (Wolf 1997[1982]:6) 
Ethnicity is a much debated and contested concept in the social and historical sciences. It is a controversial concept, as it is part of a long tradition of externally categorizing and arranging people in the present and the past within evolutionary, nationalist, ethnocentric, colonialist and racist frameworks of interpretation, along with terms such as "tribe", "people" and "race". Ethnicity is also a concept intimately connected with political issues and agendas in the present. It is likewise an important concept in archaeological research; it touches upon the core of the subject and deals with questions of similarity, difference and essence as well as the categorization and definition of groups and domains.

Ethnicity as an analytical concept and as a mode of collective identification has been the topic of many debates in anthropology and archaeology (cf. Banks 1996; Jones 1997; Eriksen 2002). The questions whether ethnicity could be a useful concept in archaeology, and if it is possible to trace prehistoric ethnic groups in the archaeological material, have been raised in a number of publications by archaeologists in Sweden (e.g., Bågenholm 1996; Johnsen \& Welinder 1998; Werbart 2002; Siapkas 2003; Welinder 2003). Furthermore, the relationships between nationalism and ethnicity and archaeological practice have been in focus in several collective works (see e.g., Díaz-Andreu \& Champion 1995; Kohl \& Fawcett 1995). Despite all the debates, ethnic, national and territorial concepts are still often used as black-boxes in archaeology, as supposedly neutral and coherent containers for interpretations of other social and cultural processes.

In the traditional culture-historical view on people in anthropology and archaeology one can observe a "one-entity syndrome", representing a desire for a single operational unit for categorizing people, a unit in which language, cultural identity, material culture and sometimes biology were fused. This syndrome is visible in the many maps and schemes produced of archaeological cultures that are fixed in space-time as bounded one-entities. Such one-entities are still part of some archaeological projects, for example in certain archaeogenetic studies (cf. Welinder 2003).

Bounded entities were (still are, in part, as we have seen) that period's way of domesticating space-time, of fixing and stabilizing, or trying to fix and stabilize - for the task is an impossible one - meanings and identities in relation to time-space. (Massey 1999:42)

In more recent discussions on ethnicity, much focus has been placed on interaction and on self-definition of ethnic identity, as a distinction made by groups of people between "us" and "them". One definition representing such an approach to ethnicity is that proposed by Siân Jones. Ethnic identity is defined as "that aspect of a person's self-conceptualization which results from identification with a broader group in opposition to others on the basis of perceived cultural differentiation and/or common descent" (Jones 1997:xiii). An ethnic group is defined as "any group of people who set themselves apart and/or are set apart by others with whom they interact, or co-exist, on the basis of their perceptions of cultural differentiation and/or common descent" (ibid.). 
In discussions on ethnicity, it is common to distinguish between a primordial and an instrumentalist approach. In the primordial perspective (Banks 1996:39ff; Jones 1997:65ff.), ethnic attachments are seen as essential, natural and universal, as an important part of human nature. Ethnicity is seen as something stable and durable that passes on through generations. Psychological aspects of individuals' sense of identity and belonging are often central. One example of a primordialist tradition is Soviet anthropology and archaeology, where there was traditionally a strong focus on ethnogenetic research, that is, on studies of the origin and ethnohistory of the different peoples of the Soviet Union (cf. Shnirelman 1995, 1996; Tishkov 1997). Material culture, biology and language were often fused within the concept of ethnos. Archaeological assemblages and archaeological cultures were in many instances equated with ethnic groups, resulting in a mosaic of prehistoric cultures arranged in space-time as one-entities.

The instrumentalist perspective (Jones 1997:72ff; Eriksen 2002:53ff.), on the other hand, is a constructivist perspective, with ethnicity perceived as a dynamic and situational phenomenon. The emphasis is here put on the role of ethnicity in inter-group relations, on ethnicity as a form of social organization. In this perspective, ethnic groups are often seen as interest groups and ethnicity as an instrument for gaining access to economic or political resources. The division between primordialism and instrumentalism is certainly an oversimplification, with most researchers positioning themselves somewhere in between the two extremes.

As a possible way forward, Bozena Werbart has suggested that archaeologists should talk about cultural identity instead of ethnicity (Werbart 2002:29ff.). Werbart views cultural identity as a wider and more dynamic concept than ethnic identity. Cultural differences should be qualified, and the archaeologists should assume a more reflective way of thinking about differences (ibid:44). The important thing is, of course, what kind of social reality the concepts refer to. Sometimes archaeologists also use "cultural identity" or other alternative labels as one-entities and black-boxes, and the resulting visions of the past will thus be the same as before.

\section{SAAMI ARCHAEOLOGY IN SWEDEN AND SWEDISH ARCHAEOLOGY IN SÁPMI}

It is well known that studies of ethnicity in general focus on minority groups and not majority groups (cf. Banks 1996:149ff.). Most archaeological studies of ethnicity in Sweden have consequently targeted the northern part of the country and the Saami population. It is obvious that, in general, the Saami are considered ethnic, while the Swedish are seen as non-ethnic. The normal, Swedish prehistory, need not be explained, while the not normal, Saami prehistory, constantly must be argued for and defended. The controversies surrounding the Late Mesolithic settlement site at Vuollerim in the province of Lapland, and the representations of life 6000 years ago, for instance the images of people seen by some as stereotypical depictions of Nordic, non-Saami people, in the exhibitions at the museum 
in Vuollerim during the 1990s, could be seen as an example of this (cf. Loeffler 1999; Mulk \& Bayliss-Smith 1999). With the "neutral" representations of life in the Stone Age challenged and the ethnic identity of the people living at Vuollerim in the Late Mesolithic being a question of importance, it demonstrates that the Stone Age, 6000 years ago, is by no means unpolitical in northern Sweden.

The relationship between the nation-states and the Saami in the writing of prehistory has been examined mainly by archaeologists in Norway (cf. Hesjedal 2001; Hansen \& Olsen 2004). Throughout the history of archaeology, the Saami have been conceptualized as the others, in Sweden in opposition to the idea of a Swedish prehistory. In the emerging human sciences in the $19^{\text {th }}$ century, the Saami became a people without history, an ethnographic object, static and unchangeable, without potential for development, whereas the Scandinavian peoples were considered to be people with history, dynamic and progressive (Schanche \& Olsen 1985; Olsen 1986). The research on the Saami was therefore mainly a concern for ethnography and philology, while the historical and archaeological literature remained very limited well into the second half of the 20th century (Hansen \& Olsen 2004:9ff.). From having been seen by many scholars, in the early $19^{\text {th }}$ century, as the indigenous population of the northern part or of the whole of Scandinavia, the Saami became regarded, from the second half of the $19^{\text {th }}$ century, as a foreign people that had immigrated relatively late to Scandinavia from the east (Storli 1993; Hansen \& Olsen 2004:20ff.). It became important to distinguish between the Swedish or Norwegian prehistory and that of the others, which was perceived as having made no significant contribution to Scandinavian history. In the separation of the national from the other, dichotomies were applied, such as between Arctic Stone Age and Nordic Stone Age (cf. Storli 1993; Furset 1994), Arctic/Eastern Bronze Age and Nordic Bronze Age, and inland and cost in northern Sweden (cf. Bolin 1999) - thus defining two separate one-entities with few or no connection points.

During the 1980s there was a noticeable shift in archaeological research from questions about when and from where the Saami immigrated, to questions about how, when and why Saami ethnicity developed among the population in Sápmi (cf. Zachrisson 1997:15ff; Schanche 2000:84ff.). An important change in the understanding of the concept of ethnicity thus took place, based on Fredrik Barth's instrumentalist approach to ethnic groups and boundaries (Barth 1969), which was represented firstly by Norwegian archaeologists such as Knut Odner (Odner 1983) and others (e.g., Kleppe 1977; Olsen 1985). This shift in view on Saami ethnicity and history took place in the context of the ethnic revival among Saami groups, in which the Alta conflict - a conflict over the exploitation of the Alta River in northern Norway for waterpower - played an important role. It was especially among researchers in Tromsø, located in northern Norway, that the field of Saami archaeology evolved during the 1980s (Hesjedal 2001:195ff.). As a consequence, research on Saami prehistory was concentrated to the northernmost part of the country, even though the Saami settlement area stretches far to the 
south, thereby continuing the division between Norwegian and Saami archaeology. A somewhat similar process might be observed in Sweden regarding the establishment of the department of archaeology in Umeå in the 1970s. The creation of a research institution in the northern part of Sweden meant a significant contribution to and advancement of the study of the northern area. At the same time, the separation of northern and southern archaeology in Sweden has in large part continued.

Today, there is a growing acceptance that Saami prehistory is a legitimate field of study in its own right and that the formulation of research policies and ethics is the responsibility of the Saami themselves. (Schanche 2002:47)

At the same time, Saami prehistory and Saami archaeology have been considered controversial and politicized concepts within the archaeological community in Sweden (cf. Zachrisson 1994, 2004). During the last decades, Saami cultural activists have strived to question and challenge the idea of a neutral cultural heritage and the representations of Sweden as mono-ethnic in history and prehistory. In recent years, questions have been raised about greater self-determination and control over cultural heritage issues in Sápmi, by institutions based in the local Saami communities, as has been the case in Norway (cf. Skandfer 2001). The discussions include questions about the responsibility for and possible repatriation of cultural objects, especially sacred objects such as Saami drums, and human remains to Saami communities and institutions (Duoddaris 2002; cf. Edbom 2005). The debate takes place in the context of a larger global movement of indigenous populations trying to recover their history and create voices of their own in different national and international discourses on cultural heritage. Issues of repatriation, reburial and cultural rights are very important here, for instance among native groups in North America and Australia (see e.g., Swidler et al. 1997; Fforde et al. 2002).

One especially controversial field of study is the south Saami area in central Sweden, which is closer to the Swedish "heartland" than northern Sápmi. Some of the debates have concerned the ethnic attribution and meaning of the so-called lake-graves, insjögravar, from the Iron Age, and the Viking Age and Early Medieval settlement and burial site at Vivallen in the province of Härjedalen, located in the southern part of Sápmi (Zachrisson 1997, 2004; Price 2000). The long-running reindeer-grazing court case has attracted much attention, as archaeologists acted as experts for the landowners' and for the Saami villages' sides in a case where the question was to determine whether or not the Saami villages possessed traditional rights to reindeer grazing in certain areas of Härjedalen (Wennstedt Edvinger 2002; Zachrisson 2004). The landowners won in the District Court in 1996 and in the Court of Appeals in 2002. The Saami villages appealed to the Supreme Court, where the appeal was rejected. Today there are other court cases in northern Sweden where the right of Saami villages to reindeer pasture is contested (cf. Levinsson \& Melin 2005). The presence of Saami populations in 
the southern part of Sápmi in the Iron Age and Early Middle Ages has in this process been contested. These Saami groups are thus forced to define themselves and their presence in history. The attempts by Saami groups to assert their cultural heritage and make visible their history are then often termed as a misuse of archaeology. The Saami are seen as interest groups who are using ethnicity and the past as instruments for economic gains. In contrast, the use of history by the landowner groups is usually not analyzed and criticized along the same lines.

In my opinion, it is necessary to re-connect archaeology as a subject to the multi-ethnic past and present of Sweden, and to open up for the experiences and voices that were earlier silenced. In this process, I believe that it is important to resist the mystification of Saami identity and avoid essentialized understandings of Saami culture, which might lead exactly to an impression of the Saami as something homogeneous and unchanged, an ethnic stereotype (cf. Welinder 2003:128).

Thus depictions of the "time and space locked native", are not expressions of multi-vocality and empowerment. Rather, they serve to reinforce existing networks of power while effectively dis-empowering the native voice. (Conrad 2004:185)

Sápmi stretches across the Nordic countries and into the northwestern part of the Russian Federation, the Kola Peninsula; therefore, the study of Saami history and prehistory has also been part of what is in many ways a different research tradition than the western European. The Saami population in the Russian Federation is considered to be one of the indigenous peoples of the North together with several other peoples belonging to the Fenno-Ugric language family (see Vakhtin 2002). The northern indigenous populations all share the historical experience of the Russian/Slavic colonization and the incorporation into the Russian empire, then the Soviet Union and at present the Russian Federation. The notions of them as the others and of their lived landscapes as a wilderness, combined with largescale exploitations of natural resources in those areas, follow the same lines as with the Saami in the Nordic countries (Slezkine 1994:387). The Russian Federation is an enormous multi-ethnic and heterogeneous nation, with many groups considered to be native or indigenous populations. The writing of (pre-)history has been intimately connected with the multi-ethnic administrative structure of the Soviet Union and the Federation, with the past in the present becoming more important in times of instability and change in the political system, such as in the 1920s and the late 1980s and early 1990s (Shnirelman 1996). After the fall of the Soviet Union a new nationalism emerged, which has had effect also within the networks of archaeology. Different groups of people try to create a new identity within a new social and political reality, by recreating or revitalizing a culture and history of their own. In some areas, this has led to conflicts between different groups over the past. In the former Soviet republics in Transcaucasia (Armenia, Azerbajdzjan, Georgia), archaeological arguments have been used in connection with armed conflicts in order to legitimize territorial claims (Shnirelman 2001). 
The primordial perspective still prevails in many studies, and the search for connections between archaeological cultures, languages and ethnic groups, as well as between prehistoric assemblages of artifacts and present-day population groups, has remained an important theme on the research agendas. This is also the case with much of the archaeological research dealing with the northern indigenous peoples and the Saami (see e.g., Patrushev 2000; Manjuchin 2002).

\section{ACTOR-NETWORK THEORY (ANT)}

It is a theory that says that by following circulations we can get more than by defining entities, essence or provinces... a way for the social scientist... to travel from one spot to the next, from one field site to the next... (Latour 1999:20f.)

ANT is not about traced networks, but about network-tracing activity... No net exists independently of the very act of tracing it, and no tracing is done by an actor exterior to the net. A network is not a thing, but the recorded movement of a thing. The questions ANT addresses now have changed. It is no longer whether a net is a representation or a thing, a part of society or a part of a discourse or a part of nature, but what moves and how this movement is recorded. (Latour 1996:378)

The network approach suggested in this article is in part inspired by the so-called actor-network theory (ANT) and related approaches in sociology and human geography. Here, I do not intend to present any general description of this complex theoretical movement, nor to explore its roots in philosophy, but rather to focus on some aspects that might be relevant to the present discussion.

ANT is usually associated with the French sociologist Bruno Latour, but has never been a unified and coherent theoretical program. The central ideas have been developed in many directions, and ANT has emerged as an influential approach to social theory in many of the social sciences. It was started within the field of science and technology studies as a way to critically examine the construction of science and knowledge (e.g., Latour 1987, 1988). Science was analyzed as a heterogeneous project in which both humans and non-humans participate and become interconnected in actor-networks (a deliberately contradictory term; Law 1999).

One of the aims of the theoretical approach was to reintegrate the domains of nature, society and language, which had been separated by modernism and postmodernism (cf. Latour 1993). The ideas from ANT have been used in order to overcome dualistic thinking and to break down traditional dichotomies such as human-animal, nature-culture, structure-agency and local-global (see Murdoch 1997). In some respects, ANT could be described as a way of following - following actors and exploring network connections. As a way of thinking, it is more focused on relations and connections than solitary entities, on performance and movement, circulation of entities and change rather than fixed stable structures. It has also 
been characterized as a kind of ecological sociology and as part of a co-constructivist tradition (Murdoch 2001). Co-constructivism in this case means that the approach is not concentrated solely on social constructivism, that is, on analyses of social constructions of e.g. scientific knowledge, but on co-construction linking humans, animals, material things, technologies etc. in networks that are more or less durable and stable.

Here, the issue of power is central. Actors or actants, both humans and nonhumans, are enrolled in networks through processes of negotiation and translation in the constant production and reproduction of networks (Hassard et al. 1999). Some actors successfully translate other actors' wills or interests into a single will for which they speak, becoming spokespersons for the others (Latour 1987:70ff.). In a stabilized network, different actors apparently assume primordial and coherent roles and positions - they are turned into black-boxes and the supporting networks, the history, behind the actors are made invisible (cf. ibid:2f., 130f.). However, networks can be both stable and unstable; sometimes actors refuse to assume their prescribed roles in the networks. The ANT-project, in this respect, is about reality, power and resistance.

The ANT-project itself has not passed unchallenged. As has been pointed out, to follow an actor also means to share the blindness of that actor (Bowker \& Star 2000:48f.). The early approaches have also been accused of creating a new allembracing theory, a new grand narrative, and thereby of excluding the "other" in the same way as those criticized by the ANT-theorists (cf. Lee \& Brown 1994). In more recent studies, questions of otherness and spaces between networks have been of central importance, and many researchers have extended the early ideas with new perspectives. The founding figures of the movement have admitted to shortcomings with the theory and have addressed some misunderstandings of what it was first intended to be (Latour 1996, 1999). In fact, Latour and others have declared that the project of ANT is over and that they themselves have moved on, if there ever was such a project in the first place (Latour 1999; Law 1999). However, the ideas and concepts live their own lives out of reach of their old masters and have been translated and enrolled in many other projects. I do not promote the use of ideas and concepts inspired by ANT as a ready-made solution, but as one source of inspiration when studying the archaeological project, the relationships between the archaeologists and the objects they study, the representations and politics of heritage, and the uses of prehistory and history in different contexts.

\section{NETWORKS OF ARCHAEOLOGY}

A network approach could perhaps inspire the archaeological study in several different ways: as a way of following the archaeologists at work, in their travels through time and space and their mobilization of resources of heterogeneous character; as a way of following how remains from and references to other times are used in various, sometimes competing, discourses in today's society; and as a 
way of following different configurations of reality and changing relationships among humans/animals/plants/supernatural beings/natural landscape features/ artifacts through history, while avoiding some of the strict dichotomies such as nature-culture, human-nonhuman and living-dead.

When studying prehistory the researcher is attempting to arrange and manage networks within which many entities are enrolled and many relations established. The archaeological study could be described as a sort of "heterogeneous engineering" (Murdoch 1997). The archaeologist strives to situate her-/himself in a strategic "center of calculation" or "center of translation" in the network (Latour 1987:232ff.), trying to gather and execute remote control over the various elements in the network, acting as a spokesperson for the archaeological artifacts and sites. Many elements figure in archaeological networks, for example archaeologists, artifacts, colors in the ground, developers, books, maps, laboratories, money, students, professors, excavators, typology schemas, phosphate samples, pollen grains, geological formations, legislation, local populations, radiocarbon dates, ethnographic examples, databases, GIS, animal and human bones, and many more. The network is composed of entities and connections that are heterogeneous in character, and its stability is dependent on support from many other networks inside as well as outside of the walls of the archaeological establishment.

Non-humans assume very important places in the archaeological networks, and they do not always behave and align themselves as the archaeologists would prefer. We might start our analyses with humans, or start with non-humans - in the end, they have often changed properties and responsibilities with each other. Archaeologists should be in a privileged position to examine the relationships between humans and non-humans and their impact on the configurations of reality, in different times and places. Archaeological artifacts change meaning in different contexts, the most obvious being the change of meaning from their prehistoric context to their present contexts in archaeological studies, museum exhibitions, newspaper articles etc. At the same time as the artifacts change roles and meanings they serve to connect the researcher or the newspaper reader with the past context (cf. the discussion on boundary objects, Bowker \& Star 2000:296ff.). The objects bring other times and spaces into what is here and now (Murdoch 1998:360), and carry with them narratives of the past.

Such processes, of course, took place in prehistory as well. In an article about the historical construction of "Norrland", Kjel Knutsson discusses the importance of the past in on-going constructions of identities, not only with regard to the prehistory of the population of today, but also with regard to ideas about the past and relations to the past among hunters and gatherers in central and northern Sweden at the time of the Neolithisation (Knutsson 2004). Knutsson examines reinterpretations of old technologies and renewed visits to old places as a way of inscribing the past in the present and creating narratives of origins and group identities. In changes in social relations, the past is active as a structure. In reusing technologies of the past, the skilled lithic craftsperson 6000 years ago acted in a 
sense as a modern researcher, collecting and translating relics from the past, characterized by a distant gaze (ibid:65ff.).

One fundamental notion in many ANT-studies is that non-humans have the potential to act, to assume roles as actors or actants, in different networks. They can act to conserve traditions and structures as well as act to bring about change. The importance of the material is further stressed as a fabric that makes networks durable across space and time. Societies are holding together not only through social relations but also through places, things and technologies (cf. Latour 1991). Among theoretically oriented archaeologists, there has recently been increased interest in materiality as heterogeneous relationships, sometimes inspired by ANT (cf. Olsen B. 2003; Meskell 2005).

Contrary to the accusation of being too concerned with things... I claim that archaeology rather suffers from being undermaterialized. The materiality of past societies is mostly seen as the outcome of historical and social processes that are not in themselves material, leaving materiality itself with little or no causal or explanatory power for these processes. (Olsen B. 2003:90)

The changing relationship between animals and humans is another theme that is of great interest to archaeologists (cf. Ingold 1994). Of major importance for our understanding of past societies is the role of animals in the contexts of, for instance, hunting, reindeer pastoralism and domestication, and the ways it is expressed in shamanistic world-views, art, animal rituals and animal graves such as the bear graves in northern Norway and Sweden (e.g., Myrstad 1997; Jennbert 2003). Furthermore, the role of "natural" features and places in the social worlds of prehistoric peoples is a topic that has been considerably discussed in archaeology in recent years (see Bradley 2000 and many works following up on that theme). Understanding prehistoric landscapes requires a method, or a way of moving, that is not blocked by the borders of our often very rigid conceptions of what is cultural, natural, supernatural, human and non-human. This is true also with regard to archaeological studies of religion and ritual. To recognize the importance of non-humans in past and present societies would mean to be better equipped when trying to understand, or follow, different configurations of reality. In doing so, archaeologists of course can only hope to trace partial connections. The archaeologists are themselves part of the networks that they trace; archaeology will always be a partial and situated perspective.

\section{CONNECTING ACROSS THE GAPS? A NETWORK APPROACH TO IDENTITY AND CLASSIFICATION}

Everything is somehow related and everything is in motion... (Eidlitz Kuoljok 1999:15; translation by author)

As discussed above, ethnicities and territories have often been treated as nontransparent black-boxes and bounded one-entities in archaeology. The dualistic thinking, which has aimed to place all the elements of the world in separate boxes 
or categories, has powered "a model of the world as a global pool hall" (Wolf 1997[1982]:6) where the "billiard balls" only bounce off each other and never truly meet, thereby facilitating a grammar for the separation and ranking of peoples. As an alternative, with some inspiration from the actor-network theory project discussed above and the practice theory approach to ethnicity discussed by Siân Jones (Jones 1997), I discuss some tentative ideas of a relational network approach in this final section of the article.

From this point of view, ethnicity could be described as one way of connecting to others, not as a primordial attachment, nor merely as an instrumental strategy, but as one set of relationships among many others, one collective among other collectives. Certain sets of relationships may in certain situations become more important and be objectified in terms of ethnic essences and differences (cf. Jones 1997:92ff. and her discussion on Bourdieu's concepts of habitus and doxa). Ethnic categories are not given by nature, nor are they only socially constructed; in a sense, such categories might be described as co-constructed by heterogeneous associations and relationships.

Formation of networks of ethnicity involves both inclusion and exclusion, that is, both bonding within the collective and exclusion of others. Therefore, the nature of the boundaries of the networks becomes important: what/who is inside and what/who is outside and what/who may cross the boundaries. It is important to emphasize that the representations of ethnicity or ethnic groups are formed within, and simultaneously help to shape, relations of power. Identities and ethnicities are not chosen freely. Representations of ethnicity may be stable or unstable, and may be contested within the network. For instance, ideas about the ethnic representations within an ethnic group might not be shared by all its members, and the representations might be challenged by alternative interpretations. The sets of relationships are not static; they may change over time and in different circumstances, and the relationships may be understood and performed differently by the actors.

Networks of ethnicity build on other networks, for instance on cultural traditions, language or myths about the past - they are not constructed out of nothing (cf. discussion in Eriksen 2002:67ff.). Ethnic processes and ethnic representations are also related to other forms of identities and modes of difference, such as gender, age, class, religion and so on. It would be interesting to consider how much importance to attribute to ethnicity in relation to other formations of identities and to explore these relationships more in depth in each instance.

One basic point that I try to make here, following the earlier discussions on actor-network theory, is that the perspective can be widened from dealing only with relations between humans. Networks of ethnicity do not necessarily involve only people, but also for instance material culture, places and landscapes, ancestors and animals - and sometimes archaeological artifacts and locales. Identities are created not only in relation to other people, but in a play or a field with nature and the world around. Here it is possible to focus on the materiality of identity 
constructions, which is of course interesting from an archaeological point of view, and also on the significance of places and landscapes in the construction of identities. In this field the past is often important, as a resource and a structure, in the creation and re-creation of myths and narratives about group identity.

If such an approach were applied in archaeology, the emphasis would be on ethnic processes instead of on the delimiting and defining of ethnic groups, on intersecting and hybrid networks and boundaries instead of on entities - on identification as a process instead of identity as a thing (cf. Eriksen 2002), accommodating conceptualization of multiple, hybrid and creolized identities. In doing so, it might be possible to bypass some of the binary oppositions commonly used to capture difference.

The notion of heterological ethnicity as discussed by Johannes Siapkas, with inspiration from the works of Michel de Certeau (Siapkas 2003), is interesting in this context. Heterological ethnicity emphasizes the determining effect of scholarly and other discourses on the conceptualization of identities in the past: "Thus, ethnicity as a topic in the first place is an issue only because it is relevant to us" (ibid:30). Microarchaeology (Cornell \& Fahlander 2002) is another approach, aiming to overcome dichotomies and strong entities by emphasizing materiality and structurating practices, which is of interest in relation to the ideas discussed in this article.

So is there any reason at all for using ethnicity in archaeology? While ethnicity is often declared irrelevant in archaeological studies, it could be argued - as is the case also with regard to gender - that such views tend to be held by people who are in privileged positions and who do not need to confront the structures of gender and/or ethnicity. The word itself could be changed to another word, but the role played by the concept will remain of importance in archaeological studies as long as it is important in the world around archaeology. Therefore, I believe that ethnicity must be discussed in archaeology, but from another starting-point than has usually been the case, with a grammar that would make it more difficult to turn to the past for simple opportune truths that can be used to legitimize domination.

\section{CONCLUSION}

In network space the distance between different elements is not constant and metric, but depends on the relations between the elements - a relational concept of space and time (Murdoch 1998). In some cases, as discussed above in the south Saami area and the Russian Federation, more or less serious conflicts have arisen over the mapping of past and future spaces, cases where archaeological evidence and interpretations play a role. For archaeologists, it is important to take these examples seriously and try to follow multiple translations of and conflicts over places and land. The archaeological mapping, the connecting and disconnecting of elements in networks, becomes part of a "power-geometry of timespace" (cf. Massey 1999), in which the production of space and time and the 
production of power are closely related. The power dimension is more evident in certain cases, such as in northern Sweden and Transcaucasia, but nonetheless is embedded in all archaeological practice.

In my view, it is important to open up the black-boxed ethnic, national and territorial concepts used in archaeology and explore the connections and separations behind the concepts. The use of one-entities conceals the interaction between the perceived groups as well as the internal dynamics within the perceived groups. Moreover, it facilitates the arranging and ranking of cultures and peoples. Here, a network approach could be useful. What would happen if we stopped treating, for instance, what-is-considered-Saami and what-is-considered-Swedish as taken for granted black-boxes and separate one-entities, and instead saw these identities as sets of heterogeneous relations involved in many different networks stretching over time and space?

I would argue that there is a need for further discussion on the regional imbalances of archaeological research in Sweden, the positions and responsibilities of archaeologists, as well as on the relationships between professional archaeologists and minority and local populations (cf. Broadbent 2001) - a critical discussion about the networks and boundaries of archaeology. What is inside and what is outside the networks of archaeology in northern Sweden, and how will the prehistory of the North be mapped in the future?

Furthermore, in trying to overcome the dualistic thinking, one important step would be to pay more attention, in the social theory of archaeology, to what is obvious and almost goes without saying in much of the practice of archaeology: the impact of the masses of non-humans that populate the world and the web of relations between humans and things and humans and animals (cf. Latour 1993).

Maybe there is a future for a practice of following - following the tracks of humans and non-humans in the past, and following the archaeologists as they move from one place to another, from one time to another, from one idea to another. A practice of following carries with it a sense of movement, of dynamics, a focus on connections, associations and relations instead of on bounded, and polarized, entities or categories. With an emphasis on power-relations, such a perspective might be useful in discussing complex and dynamic identities, facing the challenges of a contested cultural heritage.

\section{English revised by Laura Wrang.}

\section{ACKNOWLEDGEMENTS}

Earlier versions of this paper were presented at the $22^{\text {nd }}$ Nordic Archaeology Conference in Oulu, Finland in September 2004 and at the Nordic TAG Conference in Lund, Sweden in April 2005. I am grateful to the Swedish Foundation for International Cooperation in Research and Higher Education (STINT) for awarding a scholarship to the Institute of Archaeology in Moscow, where I have written part of this paper. 


\section{REFERENCES}

Banks, M. 1996. Ethnicity: anthropological constructions. London \& New York.

Barth, F. 1969. Introduction. In: Barth, F. (Ed). Ethnic Groups and Boundaries. The social organization of culture difference. Pp. 9-38. Bergen \& Oslo.

Bolin, H. 1999. Kulturlandskapets korsvägar: Mellersta Norrland under de två sista årtusendena $f \mathrm{Kr}$. Stockholm.

Bowker, G.C. \& Star, S.L. 2000. Sorting Things Out: Classification and Its Consequences. Cambridge, Mass. \& London.

Bradley, R. 2000. An Archaeology of Natural Places. London \& New York.

Broadbent, N.D. 2001. Fulfilling the Promise... An Essay on Swedish Archaeology and Archaeology in Sweden. Current Swedish Archaeology. Vol. 9. Pp. 25-38.

Bågenholm, G. 1996. Etnicitet som problem i arkeologisk forskning. GOTARC Serie C. Arkeologiska Skrifter No 11. Göteborg.

Conrad, J. 2004. Mapping space, claiming place. The (ethno-)politics of everyday geography in northern Norway. In: Siikala, A.-L., Klein, B. \& Mathisen, S.R. (Eds). Creating Diversities - Folklore, Religion and the Politics of Heritage. Pp. 165-189. Helsinki.

Cornell, P. \& Fahlander, F. 2002. Microarchaeology, Materiality and Social Practice. Current Swedish Archaeology. Vol. 10. Pp. 21-38.

Díaz-Andreu, M. \& Champion, T.C. (Eds). 1995. Nationalism and archaeology in Europe. London.

Duoddaris 2002 = Vem äger kulturarvet? Anföranden vid konferens om återföringsfrägor vid Ajtte, Svenskt Fjäll- och Samemuseum 6-8 juni 2000. Duoddaris 20. Jokkmokk.

Edbom, G. 2005. Samiskt kulturarv i samlingar. Rapport från ett projekt om återföringsfrågor gällande samiska föremål. Jokkmokk.

Eidlitz Kuoljok, K. 1999. Moder jord och andra mödrar. Föreställningar om verkligheten bland folken $i$ norr och vår syn på den. Stockholm.

Eriksen, T. H. 1996. Historia, myt och identitet. Stockholm.

- 2002. Ethnicity and Nationalism. Anthropological Perspectives. Second Edition. London.

Fforde, C., Hubert, J. \& Turnbull, P. (Eds). 2002. The Dead and their Possessions: Repatriation in principle, policy and practice. One World Archaeology 43. London \& New York.

Furset, O.J. 1994. Arktisk steinalder og etnisitet. En forskningshistorisk analyse. Hovedfagsavhandling i arkeologi. Tromsø.

Hansen, L.-I. \& Olsen, B. 2004. Samenes historie fram til 1750. Oslo.

Hassard, J., Law, J. \& Lee, N. 1999. Preface. Organization. Vol. 6(3). Pp. 387-390.

Hesjedal, A. 2001. Samisk forhistorie i norsk arkeologi 1900-2000. Stensilserie B nr. 63. Historie og arkeologi. Tromsø.

Ingold, T. (Ed). 1994. What is an Animal? One World Archaeology 1. London \& New York.

Jennbert, K. 2003. Animal graves: dog, horse and bear. Current Swedish Archaeology. Vol. 11. Pp. 139152.

Johnsen, B. \& Welinder, S. (Eds). 1998. Etnicitet eller kultur. Östersund.

Jones, S. 1997. The archaeology of ethnicity. Constructing identities in the past and present. London \& New York.

Kleppe, E.J. 1977. Archaeological material and ethnic identification. A study of Lappish material from Varanger, Norway. Norwegian Archaeological Review. Vol. 10 (1-2). Pp. 32-46.

Knutsson, K. 2004. The Historical Construction of "Norrland". In: Knutsson, H. (Ed). Coast to Coast Arrival. Results and Reflections. Pp. 45-71. Uppsala.

Kohl, P.L. \& Fawcett, C. (Eds). 1995. Nationalism, politics and the practice of archaeology. Cambridge.

Latour, B. 1987. Science in Action: How to follow scientists and engineers through society. Cambridge, Mass.

- 1988. The Pasteurization of France. Cambridge, Mass.

- 1991. Technology is society made durable. In: Law, J. (Ed). A sociology of monsters. Essays on power, technology and domination. Pp. 103-130. London. 
- 1993. We have never been modern. Cambridge, Mass.

- 1996. On actor-network theory. A few clarifications. Soziale Welt. Vol. 47. Pp. 369-381.

- 1999. On recalling ANT. In: Law, J. \& Hassard, J. (Eds). Actor Network Theory and After. Pp. 15-25. Oxford.

Law, J. 1999. After ANT: complexity, naming and topology. In: Law, J. \& Hassard, J. (Eds). Actor Network Theory and After. Pp. 1-14. Oxford.

Lee, N. \& Brown, S. 1994. Otherness and the Actor Network: the undiscovered continent. American Behavioral Scientist. Vol. 37(6). Pp. 772-790.

Levinsson, C. \& Melin, L. 2005. Omvänd bevisbörda för samerna. Populär arkeologi. Nr. 3. P. 18.

Loeffler, D. 1999. Vuollerim, Six Thousand and Fifteen Years Ago. Current Swedish Archaeology. Vol. 7. Pp. 89-106.

-2005. Contested Landscapes/Contested Heritage - history and heritage in Sweden and their archaeological implications concerning the interpretation of the Norrlandian past. Archaeology and Environment 18. Umeå.

Lundmark, L. 1998. Så länge vi har marker. Samerna och staten under sexhundra år. Stockholm.

Manjuchin, I.S. 2002. Proischozjdenije saamov. RAN. Petrozavodsk.

Massey, D. 1999. Imagining Globalization: Power-Geometries of Time-Space. In: Brah, A., Hickman, M.J. \& Mac an Ghaill, M. (Eds). Global Futures: Migration, Environment and Globalization. Pp. 27-44. New York.

Meskell, L. (Ed). 2005. Archaeologies of Materiality. Malden, MA \& Oxford.

Mulk, I.-M. \& Bayliss-Smith, T. 1999. The representation of Sámi cultural identity in the cultural landscapes of northern Sweden: the use and misuse of archaeological knowledge. In: Ucko, P.J. \& Layton, R. (Eds). The Archaeology and Anthropology of Landscape. Shaping your landscape. One World Archaeology 30. Pp. 358-396. London \& New York.

Murdoch, J. 1997. Towards a geography of heterogeneous associations. Progress in Human Geography. Vol. 21, No. 3. Pp. 321-337.

- 1998. The Spaces of Actor-Network Theory. Geoforum. Vol. 29, No. 4. Pp. 357-374.

-2001. Ecologising sociology: Actor-Network Theory, co-construction and the problem of human exemptionalism. Sociology. Vol. 35, No. 1. Pp. 111-133.

Myrstad, R. 1997. Bjørnegraver i Nord-Norge: spor etter den samiske bjørnekulten. Stensilserie/Institutt for samfunnsvitenskap, Universitetet i Tromsø. B, historie, 46. Tromsø.

Odner, K. 1983. Finner og Terfinner: Etniske prosesser i det nordlige Fenno-Skandinavia. Oslo.

Olsen, B. 1985. Arkeologi og etnisitet: et teoretisk og empirisk bidrag. In: J.-R. Næss (Ed). Arkeologi og etnisitet. AmS-Varia Vol. 15. Pp. 25-31. Stavanger.

- 1986. Norwegian archaeology and the people without (pre-)history: or how to create a myth of a uniform past. Archaeological Review from Cambridge. Vol. 5(1). Pp. 25-43.

- 2003. Material culture after text: re-membering things. Norwegian Archaeological Review. Vol. 36, No. 2. Pp. 87-104.

Olsen, K. 2003. The touristic construction of the "Emblematic" Sámi. Acta Borealia. Vol. 20(1). Pp. 3-20.

Patrushev, V. 2000. The Early History of the Fenno-Ugric Peoples of European Russia. Oulu.

Price, N. 2000. Drum-time and Viking Age: Sámi-Norse identities in Early Medieval Scandinavia. In: Appelt, M., Berglund, J. \& Gulløv, H.C. (Eds). Identities and Cultural Contacts in the Arctic. Pp. 12-27. Copenhagen.

Saarinen, J. 1997. Tourist destinations and the production of touristic space: Lapland as an ethnic landscape. Nordia Geographical Publications. Vol. 26:1. Pp. 38-45.

Schanche, A. 2000. Graver i ur og berg. Samisk gravskikk og religion fra forhistorisk til nyere tid. Karasjok.

-2002. Saami skulls, anthropological race research and the repatriation question in Norway. In: Fforde, C., Hubert, J. \& Turnbull, P. (Eds). 2002. The Dead and their Possessions: Repatriation in principle, policy and practice. One World Archaeology 43. Pp. 47-58. London \& New York.

Schanche, A. \& Olsen, B. 1985. Var de alle nordmenn? En etnopolitisk kritikk av norsk arkeologi. In: Næss, J.-R. (Ed). Arkeologi og etnisitet. AmS-Varia 15. Pp. 87-99. Stavanger. 
Shnirelman, V.A. 1995. From internationalism to nationalism: forgotten pages of Soviet archaeology in the 1930s and 1940s. In: Kohl, P.L. \& Fawcett, C. (Eds). Nationalism, politics and the practice of archaeology. Pp. 120-138. Cambridge.

- 1996. Who Gets the Past? Competition for ancestors among Non-Russian intellectuals in Russia. Washington, D.C.

- 2001. The Value of the Past: myths, identity and politics in Transcaucasia. Osaka.

Siapkas, J. 2003. Heterological ethnicity. Conceptualizing identities in ancient Greece. Uppsala.

Skandfer, M. 2001. Etikk i forvaltning - forvaltning av etikk. Samisk kulturminnevern mellom "døde" strukturer og levende tradisjon. Viking - Norsk arkeologisk årbok. Bind LXIV. Pp. 113-131.

Slezkine, Y. 1994. Arctic Mirrors - Russia and the small peoples of the North. Ithaca \& London.

Storli, I. 1993. Fra "kultur" til "natur". Om konstitueringa av den "arktiske" steinalderen. Viking-Tidskrift for norron arkeologi. Bind LVI. Pp. 7-22.

Swidler, N., Dongoske, K.E., Anyon, R. \& Downer, A.S. (Eds). 1997. Native Americans and Archaeologists. Stepping Stones to Common Ground. Walnut Creek.

Tishkov, V. 1997. Ethnicity, nationalism and conflict in and after the Soviet Union. The mind aflame. London.

Vakhtin, N. 1992. Native Peoples of the Russian Far North. London.

Welinder, S. 2003. DNA, etnicitet, folk och folkvandringar. Göteborg.

Wennstedt Edvinger, B. 2002. Reindeer Herding and History in the Mountains of Southern Sápmi. Current Swedish Archaeology. Vol. 10. Pp. 115-136.

Werbart, B. 2002. De osynliga identiteterna. Kulturell identitet och arkeologi. Umeå.

Wolf, E.R. 1997 [1982]. Europe and the People Without History. Berkeley.

Zachrisson, I. 1994. Archaeology and politics: Saami prehistory and history in central Scandinavia. Journal of European Archaeology. Vol. 2(2). Pp. 361-368.

- 2004. Archaeology and ethics. The South Sámi example. In: Karlsson, H. (Ed). Swedish Archaeologists on Ethics. Pp. 117-131. Lindome.

Zachrisson, I. et al. 1997. Möten i Gränsland. Samer och germaner i Mellanskandinavien. Stockholm. 